\section{Calibration of the dietary data obtained from the Brazilian center of the Natural History of HPV Infection in Men study: the HIM Study}

\author{
Calibração dos dados dietéticos obtidos no \\ centro brasileiro do estudo Natural History of HPV \\ Infection in Men: o Estudo HIM
}

Juliana Araujo Teixeira 1

Maria Luiza Baggio 2

Regina Mara Fisberg 1

Dirce Maria Lobo Marchioni 1

\footnotetext{
1 Faculdade de Saúde Pública, Universidade de São Paulo, São Paulo, Brasil.

2 Instituto Ludwig de

Pesquisa sobre o Câncer,

São Paulo, Brasil.

Correspondence

D. M. L. Marchioni Departamento de Nutrição, Faculdade de Saúde Pública Universidade de São Paulo Rua Dr: Arnaldo 715, São Paulo, SP 01246-904, Brasil.

marchioni@usp.br
}

\begin{abstract}
The objective of this study was to estimate the regressions calibration for the dietary data that were measured using the quantitative food frequency questionnaire (QFFQ) in the Natural History of HPV Infection in Men: the HIM Study in Brazil. A sample of 98 individuals from the HIM study answered one QFFQ and three 24-hour recalls (24HR) at interviews. The calibration was performed using linear regression analysis in which the 24HR was the dependent variable and the QFFQ was the independent variable. Age, body mass index, physical activity, income and schooling were used as adjustment variables in the models. The geometric means between the $24 H R$ and the calibration-corrected QFFQ were statistically equal. The dispersion graphs between the instruments demonstrate increased correlation after making the correction, although there is greater dispersion of the points with worse explanatory power of the models. Identification of the regressions calibration for the dietary data of the HIM study will make it possible to estimate the effect of the diet on HPV infection, corrected for the measurement error of the QFFQ.
\end{abstract}

Diety Surveys; Questionnaires; Cohort Studies

\section{Introduction}

Quantitative food frequency questionnaires (QFFQ) are one of the most commonly used methods for evaluating habitual dietary intake in large-scale epidemiological studies, given their low cost and ease of application 1,2. However, the errors present in the measurements of the questionnaire may attenuate the estimates of the relative risks that are found, and thus diminish the statistical power of studies evaluating the relationship between diet and disease 2,3 .

Knowing that error is inherent in food intake measurements, methodological strategies have been developed in an attempt to make the measurements obtained through the QFFQ closer to the quantities actually consumed, which are estimated through reference methods that are supposedly error-free 4,5 . This methodology is called calibration and it basically can be seen as a scale adjustment to the questionnaire measurements 6 . Among parametric methods, calibration by means of linear regression is considered to be the standard 7. Through this methodology, the consumption measured using the reference method is modeled as a function of the QFFQ measurement 3,7. The linear regression models obtained through calibration studies can be used to estimate food intake that is closer to reality, taking the QFFQ values as the basis ${ }^{8}$.

Twenty-four-hours recall (24HR) is the primary instrument used in dietary surveillance 9 
and is commonly used as the reference method in calibration studies. When it is assumed that the random errors in the questionnaire and in the reference method are independent from each other $\left[\operatorname{Cov}\left(\varepsilon_{\mathrm{R},} \varepsilon_{\mathrm{Q}}\right)=0\right]$, it is not expected that the errors in the reference method will cause erroneous estimates for calibration coefficients 10 . However, studies have shown that energy intake on these self-reported instruments is underreported and this fact appears to be selective according to personal characteristics 9,11,12,13.

The Natural History of HPV Infection in Men study (the HIM Study) is a prospective multicenter cohort study that analyzes, among other factors, participants' diets by seeking to identify nutrients and/or foods that are involved in the evolution of human papillomavirus (HPV) infection in men and in the development of diseases related to HPV. The QFFQ was the method chosen for measuring the food intake of the Brazilian population of the HIM study.

This study aimed to estimate the regressions calibration for the QFFQ used in the HIM study in Brazil through multiple linear regression models, taking three $24 \mathrm{HR}$ as the reference. As part of the objective, the effect of calibration was verified by comparing the calibrated data of QFFQ with the reference method.

\section{Methods}

\section{Study population}

The design of the HIM study, funded by the National Institutes of Health (NIH), was presented in a more detailed manner in a previous paper 14. For the HIM study, conducted from 2005 to 2013, around 1,427 men from Tampa, USA; 1,429 from Cuernavaca, Mexico and 1,443 from São Paulo, Brazil, aged between 18 and 70 years were selected using convenience sampling.

Out of the 153 participants who performed the visit between January and September 2007 for the Brazilian cohort, the first 120 individuals who agreed to participate in the calibration study comprised the sub-sample. Individuals with energy consumption less than 500kcal or greater than $4,000 \mathrm{kcal}$ were excluded and thus 98 men were included in the sub-sample for the calibration study 16 .

\section{Assessment of food consumption}

The sub-sample answered one $24 \mathrm{HR}$ and one QFFQ in the baseline. After six months another 24HR and QFFQ was answered. One year later than the first interview the participants answered a last $24 \mathrm{HR}$ and QFFQ, all of them by personal interview. This study used three 24HR and the last QFFQ. The dietary methods were completed on the same day, the QFFQ first and then the $24 \mathrm{HR} 17$. The interviews last for approximately 35-45 minutes per person. For each dietary method, a manual of standardized procedures was developed.

\section{- QFFQ: test method}

The methodology for developing the QFFQ that was used in the HIM study in Brazil is available in a previously published paper 18 . This questionnaire was developed based on the dietary intake of a representative sample in the city of São Paulo that had been identified in a population-base study ${ }^{19}$. In the HIM study in Brazil, the questionnaires were answered during an interview and, for each of the 54 food items listed, the participants indicated their frequency of consumption (from 0-10 times a day, week, month or year) and the portion consumed (small, medium, large or extra large). A spreadsheet containing the nutritional composition of each food item, created using the Nutrition Data System for Research (NDSR) software, 2007 version (University of Minnesota, Minneapolis, USA), was used for calculating the energy and nutrient intake.

\section{- 24HR: reference method}

The three 24HR were answered by means of faceto-face interviews, using a standard form that was filled out using the multiple-pass method 20,21. This method consists of three elements: rapid listing, detailed description and review. In the HIM study in Brazil, the subjects were asked to describe all the foods and drinks consumed during the preceding day, from the first to the last item consumed before going to bed. After the foods consumed had been reported, the subjects were asked about the times and quantities. The data were critically reviewed by a nutritionist and undergraduate nutrition students in order to identify any discrepancies related to the descriptions of the foods or preparations consumed, or their portioning and quantification. The energy and nutrient intakes were calculated using the NDSR software. The distribution of the consumption was adjusted for within-person variability (deattenuation) by means of the method proposed by Iowa State University, using the PC-SIDE software (personal computer version of the Software for Intake Distribution Estimation version 1.0, Department of Statistics, Iowa State University, Ames, USA). 
Variables tested in the linear regression models

It is well accepted that some personal characteristics have influence in the report of dietary intake 9,11,12,13. In this study there was an attempt to minimize these effects with the inclusion of socio-demographic variables in the models. The variables tested as adjustments in the multiple linear regression models that were developed for energy and each of the nutrients were: body mass index (BMI; calculated as the weight in kilograms divided by the square of the height in meters); age (years); income, schooling and physical activity (categorized).

$\mathrm{BMI}$ and age were tested in the regression models as continuous quantitative variables. Income and schooling were transformed into dichotomous variables. Income was categorized as " 0 " when the total family income was less than \$ 1,608 and " 1 " when greater than or equal to this value. The variable schooling was categorized as " 0 " when the participant had less than 12 years of study and "1" when greater than or equal to this value.

The study participants answered the International Physical Activity Questionnaire (IPAQ; short version) 22. From the data thus obtained, they were classified as "sedentary", "insufficiently active B", "insufficiently active A", "active" or "very active" 23 .

To the physical activity variable were created two dummy variables. Physical activity I representing the active level of physical activity in relation to sedentary/insufficiently active A and $\mathrm{B}$ and physical activity II representing the very active level of physical activity in relation to sedentary/insufficiently active A and B.

\section{Statistical analysis}

\section{- Linear regression models}

The data on the nutrients measured by the QFFQ and $24 \mathrm{HR}$ were transformed into natural logarithms and adjustments for energy were made using the residuals method 24 .

Taking $\mathcal{E}_{R}$ to be the independent random errors presented by the QFFQ measurements (Q) and assuming a linear relationship between the questionnaire measurements and the true intake levels (24HR), an estimate was made for the intake level predicted by the reference measurement in relation to the measurement QFFQ $(E[R \mid Q])$, in which $\mathrm{R}$ was the dependent variable $(\mathrm{Y})$ and $\mathrm{Q}$ was the independent variable $(\mathrm{X}){ }^{10}$.

$$
\begin{gathered}
Y=\beta_{0}+\beta_{1} X+\varepsilon_{R} \Leftrightarrow \\
\hat{Y}=\hat{\beta}_{0}+\hat{\beta}_{1} X \Leftrightarrow \\
R=\hat{\beta}_{0}+\hat{\beta}_{1} Q
\end{gathered}
$$

$\hat{\beta}_{1}$, which is the slope of the straight line estimated from the regression analysis, is called the calibration coefficient and is known as $\lambda$. The literature suggests that calibration using linear regression models should be done with adjustments for possible variables $\left(C_{i}\right)$ that would influence the R measurements 9,11,12,13.

$$
R=\beta_{0}+\lambda Q+\beta_{i} C_{i}
$$

In this study, the variables of BMI, age, income, schooling and physical activity were selected to be tested in the multiple models. For energy and each nutrient within the R measurement, univariate linear regression analysis was performed and, from the above variables, the ones that presented $\mathrm{p}<0.20$ in the multiple models were selected. Next, a regression function between the R and Q measurements was produced and the selected variables were included in multiple models.

Interactions between the variables that remained in the final model were tested, but no significant interaction was observed. The assumed linear relationship between the variables was evaluated by means of the graphs on the residuals, and these showed that the models were adequate.

The QFFQ data were calibrated using the equations estimated from the regression analyses. The geometric means and respective $95 \%$ confidence intervals (95\%CI) were calculated for the QFFQ data after adjustment for energy and after calibration. Likewise, they were calculated for the 24HR after deattenuation and adjustment for energy. The Mann-Whitney U test was used to identify differences between the means of the $24 \mathrm{HR}$ and of the QFFQ calibrated and noncalibrated.

Dispersion graphs between the $24 \mathrm{HR}$ and QFFQ measurements corrected by the calibration were produced in order to assess whether there was any increase in the correlation between the instruments, with regard to protein, thiamin and phosphorous. These nutrients were chosen because of the increase in statistical power observed with the inclusion of adjustment variables in the multiple models used for the calibration.

$\mathrm{P}$ values $<0.05$ were considered statistically significant, and all analyses were performed using the Stata software release 10 (Stata Corp., College Station, USA). 


\section{Ethical issues}

This study was approved by the Research Ethics Committees of the Reference and Training Center in Sexually Transmitted Diseases and in Acquired Immune Deficiency Syndrome (CRTDST/AIDS) and of the School of Public Health of the University of São Paulo. Participation in the study was conditional on signing the free and informed consent statement.

\section{Results}

Representativeness and characterization of the sample

The participants in the calibration study presented characteristics that resembled those of the participants in the Brazilian cohort. There were no differences between the groups regarding age. Within the subsample, the mean age was $35.8 \pm 10.0$ years, compared with $37.7 \pm 11.9$ for the sample of the whole cohort $(p=0.27)$. The BMI was similar between the groups, with a mean of $25.6 \pm 4.4 \mathrm{~kg} / \mathrm{m}^{2}$ for the subsample and a mean of $26.1 \pm 3.6 \mathrm{~kg} / \mathrm{m}^{2}$ for the whole cohort $(\mathrm{p}=0.10)$. The participants in the subsample and whole cohort presented equivalent schooling and income levels ( $\mathrm{p}=0.84$ and $\mathrm{p}=0.54$, respectively). This group had a mean BMI indicating overweight and most had attended school for more than 12 years and had a family income of between $\mathrm{R} \$$ 1,001 and R \$ 3,000 (between US\$ 543 and US\$ $1,627)$ per month. In relation to levels of physical activity, $52.2 \%$ of participants were considered active, $33.7 \%$ sedentary, insufficiently active B or $\mathrm{A}$, and $14.1 \%$ very active.

\section{Calibration of the nutrient intake data}

The regression coefficients $\left(\hat{\beta}_{1}\right)$, in simple linear regression analysis, ranged from 0.06 for total fat to 0.45 for fiber. In the regressions calibration, the variable of income was the one associated with the greatest number of nutrients, followed by physical activity and age. The power of the multiple models $\left(\mathrm{R}^{2} \mathrm{a}\right)$ ranged from 0.02 for monounsaturated and polyunsaturated fat to 0.33 for phosphorous and these models presented better explanatory power in relation to simple analyses (Table 1).

The geometric means and 95\%CI for energy and nutrients measured using 24HR and QFFQ are presented in Table 2. Comparing the data from the $24 \mathrm{HR}$ (deattenuated and adjusted for energy) with the data from the QFFQ (adjusted for energy), the means are statistically equal for saturated fat, trans fat, cholesterol, vitamin $\mathrm{C}$ and calcium. The geometric means for the deattenuated and energy-adjusted 24HR measurements and for the calibration-corrected QFFQ measurements were statistically equal for energy and all the nutrients studied.

The dispersion graphs (Figure 1) between the QFFQ and 24HR values demonstrate increased correlation between the instruments after making the correction for the data calibration, although there is greater dispersion of the points with worse explanatory power of the multiple linear regression models $\left(R^{2} a\right)$.

\section{Discussion}

The HIM study is the first cohort study in Brazil for which regressions calibration were calculated to enable correction of the estimated effect measurements. Although there is debate in the current literature regarding the performance of the food frequency questionnaire 25,26,27, thereby indicating that calibration studies are needed, studies using calibration methodology are not common. The stimulus for conducting calibration studies is that they generate deattenuation factors for the relative risk (RR) estimates that are found in studies evaluating the relationship between diet and disease 25 , particularly in the case of questionnaires that have been developed and are being used for the first time, as is the case of the Brazilian QFFQ of the HIM study 28.

The models for calibrating the QFFQ for use in the HIM study in Brazil were estimated by means of multiple linear regression, in which regression was performed on three $24 \mathrm{HR}$ as a function of QFFQ and specific adjustment variable for each nutrient. According to Rosner et al. 3 , the ideal would be for the intercepts $\left(\beta_{0}\right)$ to be close to zero and for the straight-line slope $\left(\beta_{1}\right)$ to be close to one, in order to be able to affirm that bias was absent from the questionnaire. Since bias is known to be present in the questionnaire, the straight-line slope of the regression is, in practice, less than one. It was observed that the slopes of the straight lines estimated by the simple linear regression in the Brazilian HIM study were between 0.06 for total fat and 0.45 for fibers. Similar intercept values were observed by other authors in international cohort studies, in relation to calcium, iron and fiber, although for the other nutrients, the values obtained in these studies were closer to one. In the European Prospective Investigation into Cancer and Nutrition (EPIC), the values of the calibration coefficients ranged from 0.30 to 0.59 for Swiss men and from 0.23 to 0.56 for Norwegian women, for the same 
Simple and multiple linear regression models considered for calibrating the quantitative food frequency questionnaire (QFFQ) data. Natural History of HPV Infection in Men: the HIM Study, Brazil, 2007-2008.

\begin{tabular}{|c|c|c|c|c|c|c|c|c|c|c|c|c|c|}
\hline & \multicolumn{3}{|c|}{ Simple linear regression } & \multicolumn{10}{|c|}{ Multiple linear regression: regression calibration } \\
\hline & $\begin{array}{l}\beta_{1}(95 \% \mathrm{Cl}), \\
\text { in log, } \\
\text { adjusted by } \\
\text { energy }\end{array}$ & p-value * & $\mathbf{R}^{2}$ & $\begin{array}{l}\lambda(95 \% \mathrm{Cl}), \text { in } \\
\text { log, adjusted } \\
\text { by energy }\end{array}$ & $\boldsymbol{\beta}_{0}$ & Income & $\begin{array}{l}\text { Physical } \\
\text { activity I }\end{array}$ & $\begin{array}{l}\text { Physical } \\
\text { activity } \\
\text { II }\end{array}$ & $\begin{array}{c}\text { Age } \\
\text { (years) }\end{array}$ & Schooling & $\begin{array}{c}\text { BMI } \\
\left(\mathrm{kg} / \mathrm{m}^{2}\right)\end{array}$ & p-value * & $\mathbf{R}^{2} \mathbf{a}$ \\
\hline Energy (kcal) & $\begin{array}{c}0.28 \\
(0.15 ; 0.41)\end{array}$ & 0.00 & 0.16 & $\begin{array}{c}0.21 \\
(0.08 ; 0.34)\end{array}$ & 6.46 * & - & 0.08 & 0.06 & - & - & -0.014 * & 0.00 & 0.24 \\
\hline \multicolumn{14}{|l|}{ Nutrients } \\
\hline Protein (g) & $\begin{array}{c}0.15 \\
(0.04 ; 0.26)\end{array}$ & 0.01 & 0.07 & $\begin{array}{c}0.17 \\
(0.07 ; 0.27)\end{array}$ & 3.92 * & 0.02 * & - & - & -0.003 * & -0.04 * & - & 0.00 & 0.24 \\
\hline Carbohydrate (g) & $\begin{array}{c}0.25 \\
(0.09 ; 0.41)\end{array}$ & 0.00 & 0.09 & $\begin{array}{c}0.20 \\
(0.03 ; 0.37)\end{array}$ & 4.50 * & -0.01 & - & - & 0.002 * & -0.04 & - & 0.00 & 0.15 \\
\hline Dietary Fiber (g) & $\begin{array}{c}0.45 \\
(0.26 ; 0.63)\end{array}$ & 0.00 & 0.19 & $\begin{array}{c}0.45 \\
(0.26 ; 0.63)\end{array}$ & 1.55 * & - & - & - & - & - & - & 0.00 & 0.19 \\
\hline Total fat (g) & $\begin{array}{c}0.06 \\
(-0.10 ; 0.21)\end{array}$ & 0.49 & 0.00 & $\begin{array}{c}0.03 \\
(-0.14 ; 0.21)\end{array}$ & 4.27 * & - & 0.17 & 0.07 * & - & 0.04 & - & 0.09 & 0.05 \\
\hline Saturated fat (g) & $\begin{array}{c}0.18 \\
(0.02 ; 0.34)\end{array}$ & 0.03 & 0.05 & $\begin{array}{c}0.18 \\
(0.02 ; 0.34)\end{array}$ & 2.75 * & - & - & - & - & - & - & 0.03 & 0.05 \\
\hline Monounsaturated fat (g) & $\begin{array}{c}0.10 \\
(-0.04 ; 0.23)\end{array}$ & 0.15 & 0.02 & $\begin{array}{c}0.10 \\
(-0.04 ; 0.23)\end{array}$ & 3.06 * & - & - & - & - & - & - & 0.15 & 0.02 \\
\hline Polyunsaturated fat (g) & $\begin{array}{c}0.21 \\
(-0.06 ; 0.48)\end{array}$ & 0.13 & 0.02 & $\begin{array}{c}0.21 \\
(-0.06 ; 0.48)\end{array}$ & 2.38 * & - & - & - & - & - & - & 0.13 & 0.02 \\
\hline Trans fat (g) & $\begin{array}{c}0.15 \\
(-0.00 ; 0.30)\end{array}$ & 0.05 & 0.04 & $\begin{array}{c}0.19 \\
(0.01 ; 0.37)\end{array}$ & 0.10 * & - & 0.04 & 0.17 & - & - & - & 0.05 & 0.05 \\
\hline Cholesterol (mg) & $\begin{array}{c}0.13 \\
(0.03 ; 0.23)\end{array}$ & 0.01 & 0.07 & $\begin{array}{c}0.10 \\
(-0.00 ; 0.20)\end{array}$ & 5.22 * & $0.04 *$ & - & - & -0.005 * & - & - & 0.00 & 0.13 \\
\hline Vitamin A (IU) & $\begin{array}{c}0.20 \\
(0.08 ; 0.31)\end{array}$ & 0.00 & 0.10 & $\begin{array}{c}0.16 \\
(0.04 ; 0.28)\end{array}$ & 7.13 * & 0.09 * & - & - & 0.003 & - & - & 0.00 & 0.17 \\
\hline Thiamin (mg) & $\begin{array}{c}0.16 \\
(-0.03 ; 0.35)\end{array}$ & 0.09 & 0.03 & $\begin{array}{c}0.19 \\
(0.00 ; 0.37)\end{array}$ & 0.41 * & - & 0.02 & -0.09 * & - & - & 0.005 * & 0.00 & 0.14 \\
\hline Riboflavin (mg) & $\begin{array}{c}0.30 \\
(0.17 ; 0.43)\end{array}$ & 0.00 & 0.18 & $\begin{array}{c}0.30 \\
(0.17 ; 0.43)\end{array}$ & 0.46 * & - & - & - & - & - & - & 0.00 & 0.18 \\
\hline Niacin (mg) & $\begin{array}{c}0.17 \\
(0.03 ; 0.31)\end{array}$ & 0.01 & 0.06 & $\begin{array}{c}0.17 \\
(0.03 ; 0.31)\end{array}$ & 2.61 * & - & - & - & - & - & - & 0.01 & 0.06 \\
\hline Folate (mg) & $\begin{array}{c}0.28 \\
(0.13 ; 0.43)\end{array}$ & 0.00 & 0.13 & $\begin{array}{c}0.24 \\
(0.09 ; 0.39)\end{array}$ & 4.86 * & - & - & - & - & -0.05 & - & 0.00 & 0.13 \\
\hline Vitamin C (mg) & $\begin{array}{c}0.31 \\
(0.13 ; 0.48)\end{array}$ & 0.00 & 0.11 & $\begin{array}{c}0.25 \\
(0.05 ; 0.45)\end{array}$ & 3.10 * & 0.13 * & 0.20 & 0.17 & - & - & - & 0.00 & 0.14 \\
\hline Vitamin E (mg) & $\begin{array}{c}0.31 \\
(0.12 ; 0.50)\end{array}$ & 0.00 & 0.10 & $\begin{array}{c}0.31 \\
(0.12 ; 0.50)\end{array}$ & 1.45 * & - & - & - & - & - & - & 0.00 & 0.10 \\
\hline Calcium (mg) & $\begin{array}{c}0.43(0.30 \\
0.55)\end{array}$ & 0.00 & 0.32 & $\begin{array}{c}0.43 \\
(0.30 ; 0.55)\end{array}$ & 3.83 * & - & - & - & - & - & - & 0.00 & 0.32 \\
\hline Phosphorous (mg) & $\begin{array}{c}0.36 \\
(0.24 ; 0.49)\end{array}$ & 0.00 & 0.25 & $\begin{array}{c}0.35 \\
(0.21 ; 0.48)\end{array}$ & 4.80 * & 0.02 * & - & - & -0.003 * & - & - & 0.00 & 0.33 \\
\hline Iron (mg) & $\begin{array}{c}0.40 \\
(0.22 ; 0.58)\end{array}$ & 0.00 & 0.16 & $\begin{array}{c}0.37 \\
(0.18 ; 0.56)\end{array}$ & 1.92 * & - & 0.02 & -0.10 * & - & - & - & 0.00 & 0.21 \\
\hline
\end{tabular}

95\% Cl: 95\% confidence interval; BMI: body mass index; log: natural logarithm.

${ }^{*} p<0.05$ : the variable is statistically significant. 
Geometric means and $95 \%$ confidence interval $(95 \% \mathrm{Cl})$ for quantitative food frequency questionnaire (QFFQ) and $24-$ hours recall (24HR) values with the deattenuated nutrient data, adjusted for energy and after correction by the calibration. Natural History of HPV Infection in Men: the HIM Study, Brazil, 2007-2008.

\begin{tabular}{|c|c|c|c|c|c|}
\hline & \multirow{3}{*}{$\begin{array}{c}24 \mathrm{HR} \\
\text { Geometric means (95\%IC) } \\
\text { Deattenuated and } \\
\text { adjusted by energy }\end{array}$} & \multicolumn{4}{|c|}{ QFFQ } \\
\hline & & \multicolumn{4}{|c|}{ Geometric means $(95 \% \mathrm{Cl})$} \\
\hline & & Adjusted by energy & $\mathrm{p}$-value * & $\begin{array}{c}\text { Adjusted by energy } \\
\text { and calibrated }\end{array}$ & $\mathrm{p}$-value * \\
\hline Energy (kcal) & $2,340.4(2,235.2 ; 2,450.5)$ & $2,111.8(1,976.4 ; 2,256.5)$ & 0.02 & $2,350.2(2,255.1 ; 2,449.3)$ & 0.80 \\
\hline \multicolumn{6}{|l|}{ Nutrients } \\
\hline Protein (g) & $96.6(94.8 ; 98.4)$ & $78.1(75.5 ; 80.8)$ & 0.00 & $96.4(95.5 ; 97.3)$ & 0.73 \\
\hline Carbohydrate (g) & $288.6(282.0 ; 295.4)$ & $260.7(253.4 ; 268.1)$ & 0.00 & $289.2(286.2 ; 292.3)$ & 0.70 \\
\hline Dietary Fiber (g) & $19.0(18.0 ; 20.0)$ & $22.9(21.7 ; 24.1)$ & 0.00 & $19.0(18.6 ; 19.4)$ & 0.81 \\
\hline Total fat (g) & $85.7(84.0 ; 87.5)$ & $81.1(79.0 ; 83.2)$ & 0.01 & $85.8(85.3 ; 86.3)$ & 0.97 \\
\hline Saturated fat (g) & $28.8(28.0 ; 29.7)$ & $28.0(27.0 ; 29.1)$ & 0.33 & $28.8(28.6 ; 29.0)$ & 0.26 \\
\hline Monounsaturated fat (g) & $29.4(28.8 ; 30.0)$ & $27.9(27.0 ; 28.8)$ & 0.03 & $29.4(29.3 ; 29.5)$ & 0.78 \\
\hline Polyunsaturated fat (g) & $19.8(19.0 ; 20.5)$ & $17.8(17.3 ; 18.3)$ & 0.00 & $19.8(19.6 ; 19.9)$ & 0.81 \\
\hline Trans fat (g) & $3.7(3.5 ; 3.9)$ & $3.9(3.7 ; 4.2)$ & 0.10 & $3.7(3.6 ; 3.8)$ & 0.59 \\
\hline Cholesterol (mg) & $270.3(257.3 ; 283.9)$ & $229.4(207.9 ; 253.1)$ & 0.06 & $267.0(261.6 ; 272.6)$ & 0.65 \\
\hline Vitamin A (IU) & $6,386.1(5,948.4 ; 6,856.0)$ & $8,583.3(7,634.8 ; 9,649.6)$ & 0.00 & $6,409.0(6,197.2 ; 6,628.0)$ & 0.97 \\
\hline Thiamin (mg) & $1.9(1.8 ; 1.9)$ & $1.6(1.5 ; 1.6)$ & 0.00 & $1.9(1.9 ; 1.9)$ & 0.48 \\
\hline Riboflavin (mg) & $1.9(1.8 ; 1.9)$ & $1.7(1.6 ; 1.8)$ & 0.00 & $1.9(1.8 ; 1.9)$ & 0.77 \\
\hline Niacin (mg) & $22.2(21.8 ; 22.7)$ & $18.1(17.5 ; 18.6)$ & 0.00 & $22.2(22.1 ; 22.4)$ & 0.64 \\
\hline Folate (mg) & $538.8(524.1 ; 554.0)$ & $394.2(380.5 ; 408.4)$ & 0.00 & $541.0(535.2 ; 546.8)$ & 0.57 \\
\hline Vitamin C (mg) & $86.0(76.2 ; 97.0)$ & $100.5(88.1 ; 114.8)$ & 0.07 & $85.9(81.1 ; 90.9)$ & 0.83 \\
\hline Vitamin E (mg) & $7.3(7.1 ; 7.6)$ & $5.8(5.6 ; 6.0)$ & 0.00 & $7.3(7.2 ; 7.4)$ & 0.76 \\
\hline Calcium (mg) & $795.1(758.8 ; 833.1)$ & 774.5 (728.1-823.9) & 0.41 & 795.9 (776.0; 816.4) & 0.83 \\
\hline Phosphorous (mg) & $1,327.0(1,297.9 ; 1,356.8)$ & $1,232.7(1,195.4 ; 1,271.2)$ & 0.00 & $1,325.3(1,307.7 ; 1,343.2)$ & 0.83 \\
\hline Iron (mg) & $17.8(17.4 ; 18.3)$ & $13.4(13.0 ; 13.8)$ & 0.00 & $17.8(17.6 ; 18.1)$ & 0.96 \\
\hline
\end{tabular}

${ }^{\star} \mathrm{p}<0.05$ : there is difference between geometric means from $24 \mathrm{HR}$ and QFFQ.

nutrients investigated 29,30 . Direct comparison of the data obtained in calibration studies such as the current study on the QFFQ for the HIM study in Brazil, with data from previous investigations, should be done cautiously because of the variations in the data analysis methodology. The EPIC studies cited above used the same instrument as the reference method (24HR), but the number of repetitions, the sample sizes and the nature of the population groups differed 29,30,31.

The models obtained in the multiple regression analyses can be applied to correct the RR obtained in the main study ${ }^{32}$. The observed attenuation of the regression coefficients values $\left(\beta_{1}\right)$ may have been a reflection of the presence of random errors in the QFFQ measurements used in the HIM study in Brazil 33. This attenuation may also have occurred through violation of the theoretical assumptions of the calibration method 16. For the calibration coefficients, considered in this study as the regressions calibration (the complete model), to provide a valid correction of the relative risk estimates, it needs to be assumed that the errors in the reference method (in this case, 24HR) and in the QFFQ are not correlated $3,29,32,34$. However, the errors in the two instruments probably do have a positive correlation, and this causes diminishment of the correlation coefficients 29 . To estimate the regressions calibration in the HIM study in Brazil, data from the 24HR and QFFQ were used with adjustments for energy as a means of reducing the correlation between the errors 16,29 .

When there is a strong correlation between the consumption of a nutrient and energy, the true relationship between this nutrient and a given disease cannot be identified from analysis of the results obtained 35 . The adjustment for energy is made with the aim of estimating the consumed quantity of a specific nutrient, independent of 
Figure 1

Dispersion graphs between the deattenuated energy-adjusted 24-hour recall (24HR) values and the energy-adjusted calibration-corrected quantitative food frequency questionnaire (QFFQ) values, for protein, thiamin and phosphorous. Natural History of HPV Infection in Men: the HIM Study, Brazil, 2007-2008.
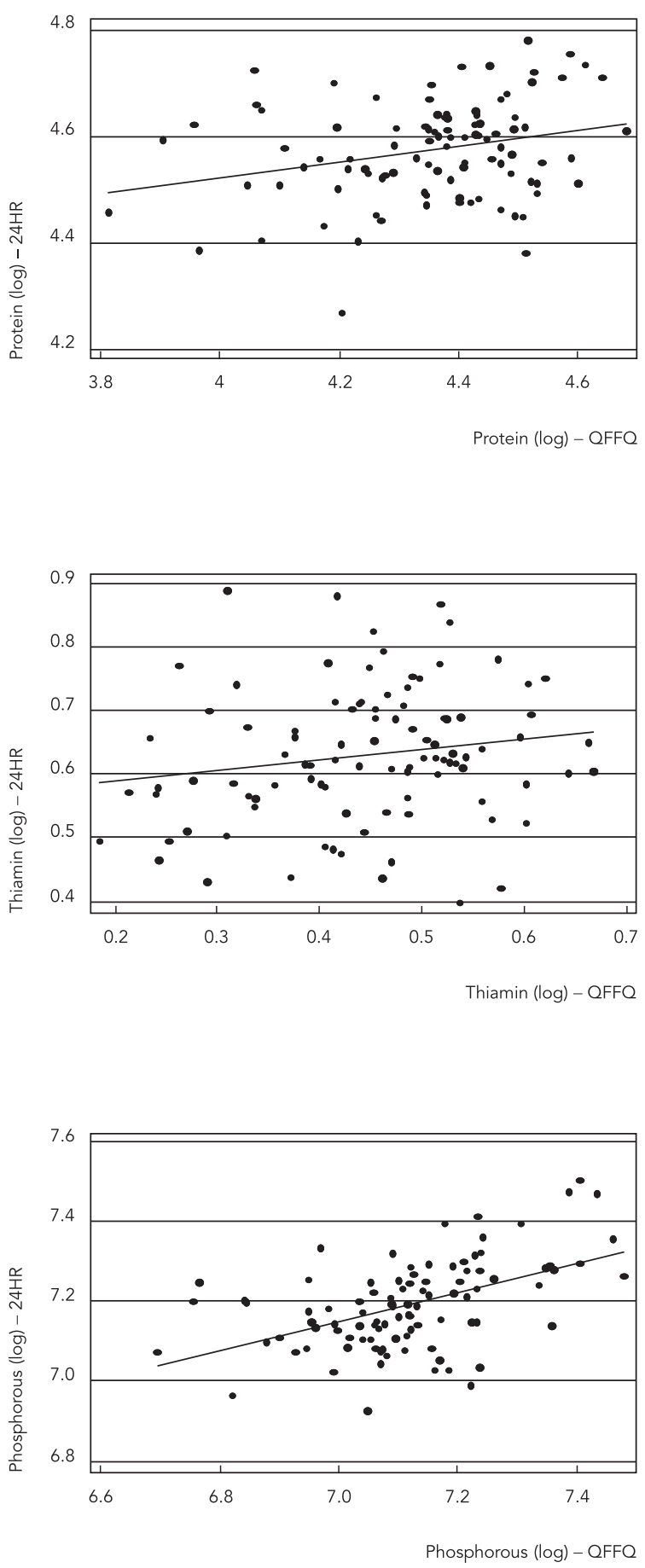
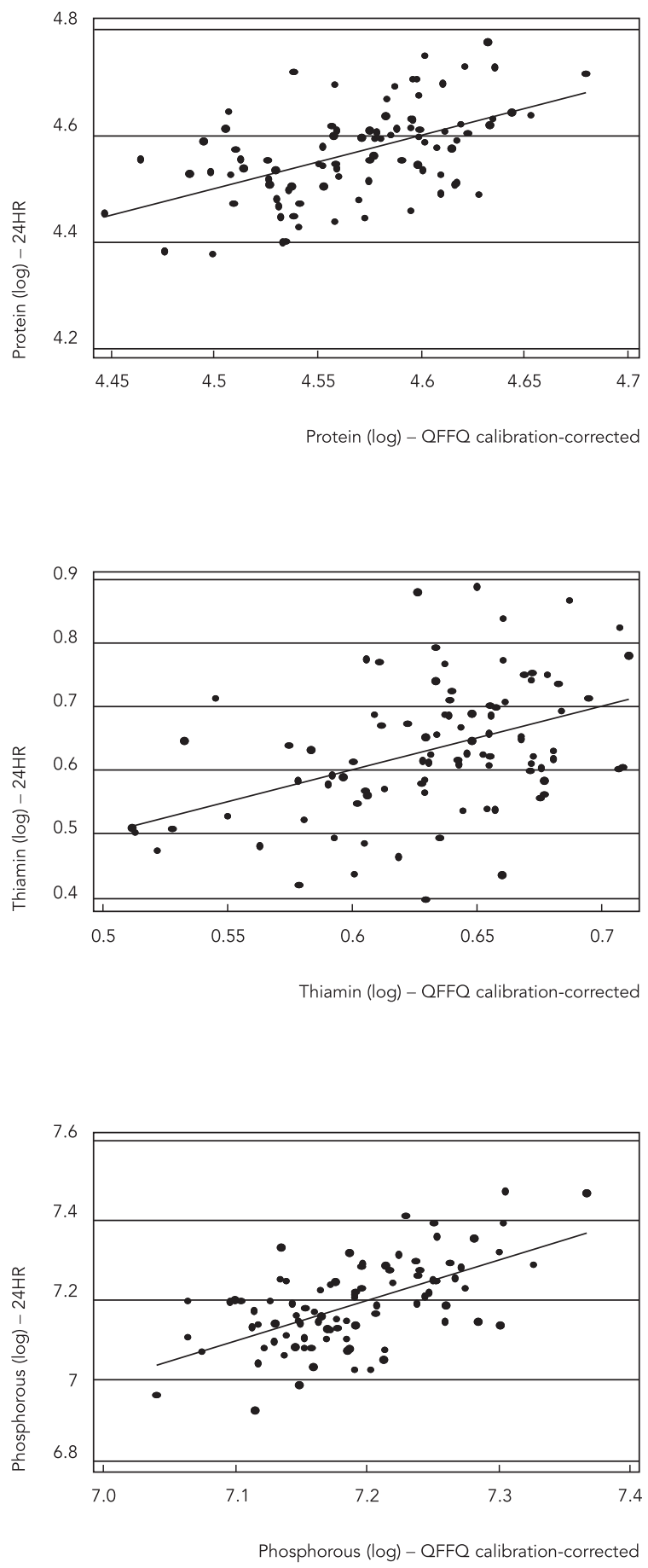
the quantity of energy consumed. As expected, after adjustment for energy in the present study, it was observed that there was no change in the geometric mean consumption: only the confidence interval decreased, thereby suggesting that the precision in estimating the value increased (data not presented).

The method used as the reference for calibrating the QFFQ for the HIM study in Brazil has the characteristic of high within-person variability, because of the unstable nature of individuals' diets. Nonetheless, it is commonly used in this type of study 10 . The variability may be diminished through increasing the number of repetitions of the reference method and the sample size 10,36. One precaution taken in the present calibration study was to make the measurements of the reference method as close as possible to the habitual intake, before including them in the model. By using the 24HR three times, it was possible to adjust the energy and nutrient consumption for the within-person variability. These adjustments were made in an attempt to minimize the errors through correcting for the distribution of the consumption. The method used for this adjustment has been indicated as one of the most efficient methods for estimating habitual intake 37 . Therefore, it was assumed that the number of repetitions of the $24 \mathrm{HR}$ that were performed, together with the deattenuation of the data, was sufficient to diminish the withinperson variation.

Some studies have shown that personal and socioeconomic characteristics have an influence on food consumption reports. Underreporting has been shown to be more prevalent among women, rather than men and seems to be more common among older people than among younger. Overweight is also associated with underreporting 9,38,39,40 as well as year of study and education appear to be independent predictors of underreporting ${ }^{38}$. When comparing underreporters with those people with report accurately, underreporters tend to report being less physically active 40 . Because of these factors it was decided to test and include adjustment variables in the multiple linear regressions, thereby enabling better estimates of the regression calibration and increasing the explanatory power of the models $41,42,43,44$. One example can be given by the correction of the protein consumption data of the QFFQ through the calibration: the simple linear regression between the deattenuated $24 \mathrm{HR}$ data and the energy-adjusted QFFQ data produced an estimated regression coefficient of 0.15 (95\%CI: 0.04-0.26), with an explanatory power for the model of $0.07\left(R^{2}\right)$. When other variables were included the power of the model increased to
$0.24\left(R^{2} a\right)$. When the equation from multiple regression on the QFFQ data was applied, it was seen from the dispersion graph that a clear adjustment of the data had occurred in relation to the $24 \mathrm{HR}$. The inclusion of other variables in the model made it possible for the QFFQ values to be brought close to those of the reference model, thereby indicating the importance of evaluating the model in its entirety, in interpreting the data, and not just the regression coefficients or calibration factors. However, the explanatory power of the models was not presented in other calibration studies, which made comparisons impossible.

Both for energy and for all the nutrients evaluated, the confidence interval of the QFFQ data decreased after the correction according to the calibration, while statistical differences between calibrated data and data from the reference method disappear. Just as in studies in other countries, the same behavior in relation to standard deviations was described in a study on adolescents in Brazil 45,46,47. This adjustment of the distribution occurred through correction of the classification errors among individuals. Extreme values were especially affected because this was a linear regression to which the instruments were subjected ${ }^{5}$.

A limitation that can be pointed is that the sample of the calibration study was selected by convenience. The principal problem of this kind of sampling is that it can lead to a group that is not representative of the population under study. The representativeness of the sub-sample was tested and the participants of the calibration study represent the population of the HIM study as they do not show statistical differences regarding age, body mass index, education and income.

The use of dietary data generated by the QFFQ in epidemiological studies without any type of correction may explain the conflicting results or inconsistencies presented in some of them 3,16 , including studies that evaluated the influence of diet on the process of infection by HPV and the development of lesions relating to the virus. However, after correction of QFFQ data based on linear regression analyses in which the reference method is as much based on reports as the QFFQ is, and is subject to similar errors, the relative risks may be biased 48,49 . Biomarkers can be used to make consumption measurements more accurate and consequently also the relative risk estimates. However, only a limited number of biomarkers are known and, even so, their use in large-scale studies is not viable because of the high costs involved ${ }^{50}$. In any event, the use of reference methods based on reports for calibrating dietary data is still more attractive than using the 
crude data in studies that evaluate the relationship between diet and disease 32 .

\section{Conclusion}

In the present study, the results from the calibration of the QFFQ that was used in the HIM study in Brazil were presented. The minimization of the measurement errors through correcting the data according to the calibration was expected. However, to analyze the relationships between dietary factors and the history of HPV infection in men, data with and without correction by the calibration should be used comparatively.

\section{Resumo}

O objetivo foi estimar as regressões de calibração dos dados dietéticos mensurados pelo questionário quantitativo de freqüência alimentar (QQFA) utilizado no Natural History of HPV Infection in Men: o Estudo HIM. Uma amostra de 98 indivíduos do estudo HIM respondeu, por meio de entrevista, a um QQFA e três recordatórios de 24 horas (R24h). A calibração foi feita por meio de análise de regressão linear, tendo os $R 24 \mathrm{~h}$ como variável dependente e o QQFA como variável independente. Idade, indice de massa corporal, atividade física, renda e escolaridade foram utilizadas como variáveis de ajuste nos modelos. As médias geométricas dos R24h e do QQFA corrigido pela calibração são estatisticamente iguais. Os gráficos de dispersão entre os instrumentos demonstraram aumento da correlação após a correção dos dados, porém observa-se maior dispersão dos pontos de acordo com a piora do poder explicativo dos modelos. A identificação das regressões de calibração dos dados dietéticos do estudo HIM permitirá a estimativa do efeito da dieta sobre a infecção por HPV, corrigida pelo erro de medida do QQFA.

Inquéritos sobre Dietas; Questionários; Estudos de Coorte

\section{Contributors}

J. A. Teixeira participated in the analysis and interpretation of the data, and in the write up of the article. M. L. Baggio collaborated on the project and conception of the article. R. M. Fisberg contributed towards the project and article conception and approved the final version for publication. D. M. L. Marchioni also participated in the project and article conception, data interpretation and critical review of the relevant content.

\section{Acknowledgments}

We are grateful to the principal investigator from the Natural History of HPV Infection in Men: the HIM Study, Anna Giuliano, and to the co-investigator Luisa Lina Villa for making available the data, as well as making important contributions. We wish to thank the Reference Center in STD/AIDS where the data were collected. We would also like to thank Lenice Galan, Filomena Cernicchiaro, Vera L. Souza, Elisa Brito, Birgit Fietzek, Raquel Hessel, Keny Seiji Kawamura, Bruna Lourenço Januario e Uerá Chechia for their contribution in the data collection and data input. 


\section{References}

1. Bingham SA, Luben R, Welch A, Wareham N, KhawK, Day N. Are imprecise methods obscuring a relation between fat and breast cancer? Lancet 2003; 362:212-4.

2. Kaaks R, Ferrari P. Dietary intake assessment in epidemiology: can we know what we are measuring? Ann Epidemiol 2006; 16:377-80.

3. Rosner B, Willett WC, Spiegelman D. Correction of logistic regression relative risk estimates and confidence intervals for systematic within-person measurement error. Stat Med 1989; 8:1051-69.

4. Beaton GH. Approaches to analysis of dietary data: relationship between planned analyses and choice of methodology. Am J Clin Nutr 1994; 59 (1 Suppl):253S-61S.

5. Kynast-Wolf G, Becker N, Kroke A, Brandstetter BR, Wahrendorf J, Boeing H. Linear regression calibration: theoretical framework and empirical results in EPIC, Germany. Ann Nutr Metab 2002; 46:2-8.

6. Riboli E, Kaaks R. Invited commentary: the challenge of multi-center cohort studies in the search for diet and cancer links. Am J Epidemiol 2000; 151:371-4.

7. Stram DO, Hankin JH, Wilkens LR, Pike MC, Monroe KR, Park S, et al. Calibration of the dietary questionnaire for a multiethnic cohort in Hawaii and Los Angeles. Am J Epidemiol 2000; 151:358-70.

8. Ferrari P, Day NE, Boshuizen HC, Roddmam A, Hoffmann K, Thiébaut A, et al. The evaluation of the diet/disease relation in the EPIC study: considerations for the calibration and the disease models. Int J Epidemiol 2008; 37:368-78.

9. Tooze JA, Subar AF, Thompson FE, Troiano R, Schatzkin A, Kipnis V. Psychosocial predictors of energy underreporting in a large doubly labeled water study. Am J Clin Nutr 2004; 79:795-804.

10. Kaaks R, Riboli E. Validation and calibration of dietary intake measurements in the EPIC project: methodological considerations. European Prospective Investigation into Cancer and Nutrition. Int J Epidemiol 1997; 26 Suppl 1:S15-25.

11. Macdiarmid J, Blundell J. Assessing dietary intake: who, what and why of under-reporting. Nutr Res Rev 1998; 11:231-53.

12. Hill RJ, Davies PS. The validity of self-reported energy intake as determined using the doubly labelled water technique. Br J Nutr 2001; 85:415-30.

13. Trabulsi J, Schoeller DA. Evaluation of dietary assessment instruments against doubly labeled water, a biomarker of habitual energy intake. Am J Physiol Endocrinol Metab 2001; 281:E891-9.

14. Giuliano AR, Lazcano-Ponce E, Villa LL, Flores R, Salmeron J, Lee JH, et al. The human papillomavirus infection in men study: human papillomavirus prevalence and typo distribution among men residing in Brazil, Mexico, and United States. Cancer Epidemiol Biomarkers Prev 2008; 17:2036-43.

15. Instituto Brasileiro de Geografia e Estatística. Censo demográfico 2000: características da população e dos domicílios. Rio de Janeiro: Instituto Brasileiro de Geografia e Estatística; 2001.

16. Willett WC. Nutritional epidemiology. $2^{\text {nd }}$ Ed. New York: Oxford University Press; 1998.
17. Cade J, Thompson R, Burley V, Warm D. Development, validation and utilization of food-frequency questionnaires: a review. Public Health Nutr 2002; 5:567-87.

18. Fisberg RM, Colucci ACA, Morimoto JM, Marchioni DML. Questionário de freqüência alimentar para adultos com base em estudo populacional. Rev Saúde Pública 2008; 42:550-4.

19. César CLG, Carandina L, Alves MCGP, Barros MBA, Goldbaum. Saúde e condição de vida em São Paulo. Inquérito multicêntrico de saúde no estado de São Paulo - ISA-SP. São Paulo: Faculdade de Saúde Pública, Universidade de São Paulo; 2005.

20. Johnson RK, Driscoll P, Goran MI. Comparison of multiple-pass 24-hour recall estimates of energy intake with total energy expenditure determined by doubly labeled water method in young children. J Am Diet Assoc 1996; 96:1140-4.

21. Guenther PM, Cleveland LE, Ingwersen LA, Berline M. Questionnaire development and data collection procedures. In: Tippett KS, Cypel YS, editors. Design and operation: the continuing survey of food intakes by individuals and the Diet and Health Knowledge Survey, 1994-1996. Beltsville: United States Department of Agriculture; 1998. p 42-63. (Nationwide Food Surveys Report, 96-1).

22. Craig CL, Marshall AL, Sjöström M, Bauman AE, Booth ML, Ainsworth BE, et al. International physical activity questionnaire: 12-country reliability and validity. Med Sci Sports Exerc 2003; 35:1381-95.

23. Matsudo S, Araújo T, Matsudo V, Andrade D, Oliveira L, Braggion G. Nível de atividade física da população do Estado de São Paulo: análise de acordo com o gênero, idade, nível sócio-econômico, distribuição geográfica e de conhecimento. Rev Bras Ciênc Mov 2002; 10:44-50.

24. Willett W, Stampfer MJ. Total energy intake: implications for epidemiological analyses. Am J Epidemiol 1986; 124:17-27.

25. Willett W. Invited commentary: OPEN questions. Am J Epidemiol 2003; 158:22-4.

26. Subar AF, Kipnis V, Troiano RP, Midthune D, Schoeller DA, Bingham S, et al. Using intake biomarkers to evaluate the extent of dietary misreporting in a large sample of adults: The OPEN Study. Am J Epidemiol 2003; 158:1-13.

27. Kipnis V, Subar AF, Midthune D, Freedman LS, Ballard-Barbash R, Troiano RP, et al. The structure of dietary measurement error: Results of the OPEN biomarker study. Am J Epidemiol 2003; 158:14-21.

28. Shai I, Rosner BA, Shahar DR, Vardi H, Azrad AB, Kanfi A, et al. Dietary evaluation and attenuation of relative risk: multiple comparisons between blood and urinary biomarkers, food frequency, and 24-hour recall questionnaires: the DEARR Study. J Nutr 2005; 135:573-9.

29. Johansson I, Hallmans G, Wikman A, Biessy C, Riboli E, Kaaks R. Validation and calibration of food-frequency questionnaire measurements in the Northern Sweden Health and Disease cohort. Public Health Nutr 2002; 5:487-96. 
30. Hjartaker A, Andersen LF, Lund E. Comparison of diet measures from a food-frequency questionnaire with measures from repeated 24-hour dietary recalls. The Norwegian Women and Cancer Study. Public Health Nutr 2007; 10:1094-103.

31. Subar AF, Thompson FE, Kipnis V, Midthune D, Hurwitz P, McNutt S, et al. Comparative validation of the Block, Willett, and National Cancer Institute food frequency questionnaire. Am J Epidemiol 2001; 154:1089-99.

32. Thiébaut ACM, Freedman LS, Carroll RJ, Kipnis V. Is it necessary to correct for measurement error in nutritional epidemiology? Ann Intern Med 2007; 146:65-7.

33. Kaaks R, Riboli E, Staveren WV. Calibration of dietary intake measurement in prospective cohort studies. Am J Epidemiol 1995; 142:548-56.

34. Kipnis V, Midthune D, Freedman LS, Bingham S, Schatzkin A, Subar A, et al. Empirical evidence of correlated biases in dietary assessment instruments and its implications. Am J Epidemiol 2001; 153:394-403.

35. Thompson FE, Byers T. Dietary assessment resource manual. J Nutr 1994; 124(11 Suppl):2245S$317 \mathrm{~S}$.

36. Beaton GH, Milner J, Corey P, McGuire V, Cousins M, Stewart E, et al. Sources of variance in 24-hour dietary recall data: implications for nutrition study design and interpretation. Am J Clin Nutr 1979; 32:2546-59.

37. Hoffmann K, Boeing H, Dufour A, Volatier JL, Telman J, Virtanen M, et al. Estimating the distribution of usual dietary intake bay short-term measurements. Eur J Clin Nutr 2002; 56 Suppl 2:S53-62.

38. Hirvonen T, Männistö S, Roos E, Pietinen P. Increasing prevalence of underreporting does not necessarily distort dietary surveys. Eur J Clin Nutr 1997; 51:297-301.

39. Johnson RK, Soultanakis RP, Matthews DE. Literacy and body fatness are associated with underreporting of energy intake in US low-income women using the multiple-pass 24-hour recall: a doubly labeled water study. J Am Diet Assoc 1998; 98: 1136-40.

40. Krebs-Smith SM, Graubard BI, Kahle LL, Subar AF, Cleveland LE, Ballard-Barbash R. Low energy reporters vs. others: a comparison of reported food intakes. Eur J Clin Nutr 2000; 54:281-7.
41. Crispim SP, Ribeiro RCL, Silva MMS, Rosado LEFP, Rosado GP. The influence of education in the validation process of a food frequency questionnaire for adults in Viçosa, Minas Gerais, Brazil. Eur J Clin Nutr 2006; 60:1311-6.

42. Marks GC, Hughes MC, van der Pols JC. The effect of personal characteristics on the validity of nutrient intakes estimates using a food-frequency questionnaire. Public Health Nutr 2006; 9:394-402.

43. Olafsdottir AS, Thorsdottir I, Gunnarsdottir I, Thorgeirsdottir H, Steingrimsdottir L. Comparison of women's diet assessed by FFQs and 24-hour recalls with and without underreporters: associations with biomarkers. Ann Nutr Metab 2006; 50:450-60.

44. Paalanen L, Männistö S, Virtanen MJ, Knekt P, Räsänen L, Montonen J, et al. Validity of a food frequency questionnaire varied by age and body mass index. J Clin Epidemiol 2006; 59:994-1001.

45. Sempos CT, Looker AC, Johnson CL, Woteki CE. The importance of within-person variability in estimating prevalence. In: MacDonald I, editor. Monitoring dietary intakes. New York: SpringerVerlag; 1991. p. 99-109.

46. Kipnis V, Midthune D, Freedman L, Bingham S, Day NE, Riboli E, et al. Bias in dietary-report instruments and its implications for nutritional epidemiology. Public Health Nutr 2002; 5:915-23.

47. Slater B, Marchioni DML, Voci SM. Aplicação de regressão linear para correção de dados dietéticos. Rev Saúde Pública 2007; 41:190-6.

48. Wacholder S, Armstrong B, Hartge P. Validation studies using an alloyed gold standard. Am J Epidemiol 1993; 137:1251-8.

49. Kipnis V, Carroll RJ, Freedman LS, Li L. Implications of a new dietary measurement error model for estimation of relative risk: application to four calibration studies. Am J Epidemiol 1999; 150:642-51.

50. Kaaks R, Ferrari P, Ciampi A, Plummer M, Riboli E. Uses and limitations of statistical accounting for random error correlations, in the validation of dietary questionnaire assessments. Public Health Nutr 2002; 5:969-76.

Submitted on 10/Sep/2009

Final version resubmitted on 10/May/2010

Approved on 21/May/2010 